\title{
Implementasi Strategi Membaca Berimbang di Kelas Awal Madrasah Ibtidaiyah (MI) di Semarang
}

\author{
Zulaikhah \& Sayyidatul Fadlilah \\ Universitas Islam Negeri Walisongo Semarang \\ Email: zulaikhahtaufik@yahoo.co.id \\ sayyidatul_fadhilah@walisongo.ac.id
}

\begin{abstract}
Abstrct: This study aims at describing the implementation of impartial reading strategies namely collective reading, guided reading, and independent reading performed by teachers of early grades at Islamic Elementary School (MI and MIN) in six madrassas in Semarang. Implementation is conducted after the training of impartial reading is made and continued by providing assistance to teachers in creating impartial reading programs, applying impartial reading strategies, organizing the variety and types of books, and managing students in impartial reading. The program is focused on the use of books containing Islamic values as the development of modules or manuals that have been used to implement the strategy.
\end{abstract}

Abstrak: Artikel ini bertujuan untuk mendeskripsikan implementasi strategi-strategi membaca berimbang, membaca bersama, membaca terbimbing, dan membaca mandiri, yang dilakukan oleh guru-guru kelas awal di lingkungan Madrasah Ibtidaiyah (MI dan MIN) di Semarang. Implementasi dilakukan setelah diberikan pelatihan menerapkan Membaca Berimbang dan dilanjutkan dengan memberikan pendampingan terhadap guru-guru tersebut dalam membuat program membaca berimbang, menerapkan strategi membaca berimbang, mengelola ragam dan jenis buku bacaan, dan mengelola siswa dalam membaca berimbang. Program ini difokuskan pada penggunaan buku-buku yang mengandung nilai-nilai keislaman sebagai pengembangan dari modul atau buku panduan yang telah digunakan untuk mengimplementasikan strategi tersebut.

Kata Kunci: Kompetensi Pedagogik, membaca berimbang, membaca bersama, membaca terbimbing 


\section{PENDAHULUAN}

Membaca adalah perintah Allah pertama yang ditujukan kepada seluruh umat manusia. Membaca ayat-ayat Allah baik yang bersifat qauliyah maupun kauniyah dilakukan dengan tujuan untuk mendapatkan berbagai informasi dan beragam pengetahuan, untuk meningkatkan kompetensi dan kreatifitas, serta meraih derajat tertinggi sebagai hamba yang mulia. Membaca merupakan sesuatu yang sentral dalam pendidikan. Kemampuan membaca seseorang akan berdampak pada kemampuan yang lain, seperti kemampuan menulis, menyimak dan berbicara.

Terdapat sejumlah hasil penelitian baik dari dalam maupun luar negeri yang mengungkap kemampuan membaca anak Indonesia, diantaranya adalah hasil penelitian dari PIRLS/Progress in International Reading Literacy Study yang menunjukkan bahwa rata-rata kemampuan membaca anak Indonesia berada pada urutan keempat dari bawah dari 45 negara di dunia (www.srie.org). Selain itu juga terdapat Hasil Asesmen Membaca Siswa Kelas Awal (Early Grade Reading Assessment - EGRA) yang dilakukan pada 4.232 siswa kelas tiga di sekolah dasar dan madrasah ibtidaiyah di 23 kabupaten di tujuh provinsi mitra USAID PRIORITAS, menunjukkan siswa kelas tiga fasih dalam membaca huruf dan membaca kata-kata tetapi memiliki kesulitan dalam membaca teks dan memahami isinya (www.prioritaspendidikan.org).

Kegiatan membaca secara terus menerus yang berujung pada terbentuknya budaya baca juga menjadi program pemerintah terutama kementerian pendidikan Nasional. Kemendiknas mengembangkan gemar membaca melalui pendidikan formal dan non formal. Untuk mendukung upaya pemerintah tersebut serta menanggulangi berbagai persoalan di atas maka, perlu dilakukan langkah kongkrit dengan menerapkan program membaca berimbang yang dapat membangun budaya baca siswa sejak awal di bangku sekolah agar budaya literasi masyarakat Indonesia juga semakin meningkat.

Peningkatan literasi dan kemampuan tentu akan sangat mendukung prestasi seorang siswa. Keadaan ini sejalan dengan konsep efek matthew yang ada dalam ilmu ekonomi dimana yang kaya akan semakin kaya sedangkan yang miskin akan semakin miskin. Dalam konteks pendidikan tentu konsep tersebut tidak diartikan demikian. Efek Matthew dalam hal ini diartikan peserta didik yang lambat dalam menyerap pelajaran akan mendapatkan hasil yang rendah, sedangkan yang menengah dan cepat akan mendapatkan hasil yang lebih baik. Oleh karena itu, tidak salah jika disimpulkan bahwa efek Matthew dapat dicegah dengan membaca. 
Untuk membangun budaya baca siswa bisa dilakukan dengan berbagai strategi dan cara diantaranya adalah menerapkan program kegiatan membaca berimbang yaitu membaca bersama, membaca terbimbing dan membaca mandiri. Untuk bisa menerapkan kegiatan membaca berimbang, guru menjadi kunci utama dalam pelaksanaan program tersebut. Karena setiap strategi membaca tersebut memiliki tujuan dan pengelolaan siswa yang berbeda-beda serta beragam sumber bacaan dan jenis bacaan yang berbeda pula, maka Guruguru harus diberikan pelatihan dan pendampingan bagaimana menerapkan berbagai strategi membaca berimbang dengan terfokus pada pengembangan kemampuan memprediksi, mengetahui penerapan tanda baca dan memahami kosakata sulit, memahami bacaan, dan cara merangkum sebuah bacaan. Selain itu guru juga dilatih dan didampingi bagaimana mengelola beragam buku dan jenis buku bacaan yang diperlukan serta dilatih dan didampingi dalam mengelola siswa pada saat kegiatan membaca berimbang dilakukan.

Kemampuan tersebut menjadi bagian dari komptensi pedagogik guru yang harus dikembangkan secara berkelanjutan. Kemampuan pedagogik sperti yang diutarakan Trianto (2011: 54) tercantum dalam peraturan pemerintah Nomor 74 Tahun 2008 yang merupakan kemampuan guru dalam mengelola pembelajaran peserta didik yang meliputi hal-hal seperti pemahaman wawasan dan landasan kependidikan, pemahaman terhadap peserta didik, pengembangan kurikulum atau silabus, perancangan pembelajaran, pelaksanaan pembelajaran yang mendidik dan dialogis, pemanfaatan teknologi pembelajaran, evaluasi pembelajaran, dan pengembangan peserta didik agar mampu mengaktualisasikan berbagai potensi yang dimilliki. Sedangkan Darmadi dan Hamid (2010:32) menambahkan lima sub komtensi pedagogik yang meliputi pemahaman peserta didik secara mendalam, perancangan pembelajaran, pelaksanaan pembelajaran, perancangan dan pelaksanaan evaluasi pembelajaran, serta pengembangan untuk aktualisasi diri potensi peserta didik.

Guru di kelas awal memiliki peran yang sangat penting dalam mengembangkan kemampuan dan keterampilan awal siswa dalam membaca. Kegiatan membaca sangat membutuhkan bahan-bahan bacaan yang sesuai, misalnya dalam kegiatan membaca bersama diperlukan sebuah buku besar/bigbook atau buku bacaan atau buku cerita bergambar. Dalam kegiatan membaca terbimbing dibutuhkan buku bacaan berjenjang/levelling text untuk siswa dengan kemampuan membaca yang beragam, sedangkan untuk kegiatan membaca mandiri diperlukan beragam buku bacan berupa Bigbook/BB, Buku Bacaan Berjenjang/B3 dan Buku Cerita Bergambar/BCB atau buku-buku lainnya. Selama ini USAID PRIORITAS bekerja sama dengan UIN Walisongo 
semarang yang merupakan mitra dari beberapa sekolah Madrasah Ibtidaiyah Negeri (MIN) maupun Madrasah Ibtidaiyah (MI) di Semarang dan telah memberikan bantuan sejumlah lebih dari 600 buah buku bacaan. Maka, untuk memaksimalkan pemanfaatan dan penggunaannya buku tersebut perlu diberikan pelatihan dan pendampingan bagi kepala sekolah dan guru-guru di kelas awal.

Guru kelas awal ditentukan sebagai batasan karena beberapa alasan. Pertama, pengembangan kemampuan membaca siswa kelas awal menjadi tanggung jawab guru kelas dan kuncinya ada di guru kelas. Kedua, kegiatan pendampingan membutuhkan perhatian, waktu, tenaga dan banyaknya aspek yang harus diperhatikan. Oleh karena itu, guru-guru kelas awal perlu diberikan pelatihan khusus sekaligus pendampingan intensif agar mereka mampu membuat program membaca berimbang dan dapat menerapkannya pada siswasiswi di kelas awal. Proses pendampingan menekankan pada pemberian coaching akan pelaksanaan strategi-strategi yang dilakukan oleh guru kelas awal dalam menerapkan Program Membaca Berimbang, membuat program membaca berimbang, mengelola bahan bacaan (Buku Besar/BB, Buku Bacaan Berjenjang/B3, dan Buku Cerita Bergambar/ BCB), serta pengelolaan siswa pada program membaca berimbang. Pendampingan tersebut juga diikuti dengan evaluasi kegiatan-kegiatan yang sudah dilaksanakan.

Artikel ini bertujuan untuk mendeskripsikan implementasi strategistrategi membaca berimbang, membaca bersama, membaca terbimbing, dan membaca mandiri, yang dilakukan oleh guru-guru kelas awal di lingkungan Madrasah Ibtidaiyah (MI dan MIN) di Semarang khususnya di enam madrasah yang menjadi mitra UIN Walisongo yang tersebar di ecamatan Ngaliyan, Kecamatan Tugu dan Kecamatan Gunung Pati Semarang. Implementasi dilakukan setelah diberikan pelatihan menerapkan Membaca Berimbang pada siswa dan dilanjutkan dengan memberikan pendampingan terhadap guru-guru tersebut dalam membuat program membaca berimbang, menerapkan strategi membaca berimbang, mengelola ragam dan jenis buku bacaan, dan mengelola siswa dalam membaca berimbang. Program ini difokuskan pada penggunaan buku-buku yang mengandung nilai-nilai keislaman sebagai pengembangan dari modul atau buku panduan yang telah digunakan untuk mengimplementasikan strategi tersebut. Diharapkan dengan pelatihan dan pendampingan ini, penerapan program membaca berimbang dapat meningkatkan kompetensi pedagogik guru dan membekali guru dengan kemampuan yang mumpuni sehingga efek Matthew dapat diminimalisir dan budaya baca pada siswa dapat tercipta. 


\section{IMPLEMENTASI STRATEGI MEMBACA BERIMBANG DI KELAS AWAL}

Upaya peningkatan kompetensi pedagogik guru kelas awal, dilakukan melalui tiga kegiatan utama yaitu pelatihan, pendampingan dan pasca pendampingan. Pelatihan merupakan kegiatan utama yang merupakan peletak landasan utama bagi peningkatan kompetensi guru. dasar utama dari kegiatan pengabdian ini. Program ini langsung diawali dengan pelatihan karena beberapa alasan diantaranya adalah madrasah dampingan yang menjadi peserta merupakan mitra yang selama ini telah mengadakan kegiatan bersama sehingga sudah cukup mengenal program dan dapat menghemat waktu.

Pelatihan menjadi program pertama dari program peningkatan kompetensi pedagogik guru. Pelatihan ini bertajuk peningkatan kompetensi paedagogis guru kelas awal dalam menerapkan strategi membaca berimbang yang merupakan kelanjutan dari program USAID Prioritas yang sudah dilaksanakan dibeberapa madrasah binaan UIN Walisongo. Tujuan awal dari pelatihan membaca berimbang ini adalah membantu guru dalam mengatasi perbedaan kemampuan membaca siswa di kelas. Dari fakta yang ada di lapangan, perbedaan selalu terjadi dimana siswa yang mempunyai kemampuan baik dalam membaca akan cenderung semakin melejit meninggalkan teman-teman yang mempunyai kemampuan kurang dalam membaca. Dengan kata lain, siswa yang cakap akan semakin cakap, sedangkan yang kurang cakap akan semakin kurang cakap. Kendala seperti ini selalu terjadi dan menjadi kendala semua guru dari waktu ke waktu. Guru yang tidak mempunyai inovasi dan kemampuan yang memadai dalam mengatasi masalah ini biasanya tidak tahu apa yang harus dilakukan dan akan membuat keadaan siswa semakin memburuk.

Pelatihan strategi membaca berimbang merupakan pelatihan yang menggunakan tiga strategi yaitu membaca bersama, terbimbing, dan mandiri. Pelatihan ini dimaksudkan untuk memudahkan dan mempercepat siswa dalam belajar membaca. Pelatihan ini dilatarbelakangi oleh kemampuan siswa kelas awal membaca yang masih rendah. Dalam pelatihan ini, guru memegang peran kunci sebagai pengguna strategi. Pelatihan ini menggunakan media buku Buku Bacaan Berjenjang (B3) yang disediakan oleh USAID. Beberapa hal yang berbeda dan sekaligua menguatkan program USAID sebelumnya adalah penekanan pada kemampuan para guru untuk mengembangkan materi dan strategi setelah memakai buku B3. Guru mampu melakukan pengembangan strategi serta materi dari buku-buku yang dibaca oleh para siswa. Materi yang paling ditekankan dalam pelatihan ini adalah materi yang memiliki nilai-nilai 
keislaman. Nilai-nilai keislaman didapatkan dari buku-buku yang dijadikan media utama yang dalam pelatihan ini diberikan kepada madrasah binaan yang menjadi peserta.

Dari beberapa perbedaan dan fokus pelatihan, ada beberapa tujuan utama yang menjadi target pelatihan ini. Hasil dari pelatihan ini diharapkan menjadi model baru dalam pengembangan strategi membaca khususnya penggunaan buku-buku B3 melalui kegiatan eksplorasi dan adaptasi kemampuan pedagogik. Secara luas, madrasah yang menjadi menerapkan strategi membaca berimbang ini akan menjadi model bagi madrasah atau sekolah lain khususnya dalam memperkuat konten keislaman melalui kegiatan dan buku-buku yang dibaca oleh siswa. Keberhasilan program ini sekaligus akan mensukseskan program pemerintah yang mencanangkan membaca setidaknya 15 menit sebelum atau sesudah kelas.

Meski pelatihan ini dikhususkan pada guru kelas awal, namun pada kenyataanya pelatihan ini diikuti oleh guru-guru yang mengajar kelas tinggi. Alasan utama dari kebijakan ini adalah kebijakan rolling yang dilakukan oleh madrasah-madrasah. Guru sering mengalami pergeseran dalam mengajar level kelas. Artinya, guru yang pada tahun akademik ini mengajar kelas awal, ada kemungkinan mereka akan diminta mengajar kelas yang lebih tinggi. Dengan kebijakan tersebut dan untuk menjamin kualitas kompetensi guru madrasah yang ada akan tetap mampu mengaplikasikan strategi tersebut, maka kebijakan peserta pelatihan diputuskan untuk diikuti oleh beberapa guru kelas awal dan tinggi dengan tanpa pengecualian.

Narasumber pelatihan ini adalah bapak Ahmad Mutohar dan Fatkuroji yang keduanya merupakan fasilitator dari USAID Prioritas. Peserta pelatihan berjumlah 41 orang yang terdiri dari kepala sekolah 6 orang dan lainnya adalah guru Madrasah Ibtidaiyah Negeri (MIN) dan Madarasah Ibtidaiyah (MI) mitra UIN Walisongo berjumlah 35 orang guru. Adapun nama-nama madrasah mitra UIN Walisongo Semarang tersebut adalah MIN Sumur Rejo kec Gunung pati, MI Walisongo kec Jrakah, MI Miftahussibyan kec Tugu, MI Miftahul Akhlaqiyah kec Ngaliyan, MI Nurul Islam kec Ngaliyan, dan MI Darul Ulum Ngaliyan.

Materi pelatihan program membaca berimbang terdiri dari program membaca bersama, program membaca terbimbing, program membaca mandiri, dan perancangan program membaca berimbang. Membaca Bersama merupakan kegiatan yang melibatkan semua siswa dalam satu kelas. Guru memodelkan berbagai keterampilan membaca dan melibatkan siswa selama proses membaca dilakukan. Selain guru yang menjadi model, siswa yang dianggap mampu juga 
bisa dijadikan model yang kemudian diikuti oleh siswa lainnya. Kegiatan ini menggunakan buku Bigbook sebagai media dimana buku tersebut digunakan secara klasikal sesuai dengan tujuan kompetensi yang dikehendaki. Fokus keterampilan yang dilatihkan dalam kegiatan Membaca Bersama adalah memprediksi, memahami kosakata dan tanda baca, memahami isi bacaan, dan merangkum/meringkas.

Kegiatan membaca terbimbing merupakan kegiatan yang dilaksanakan dibawah bimbingan guru. Kegiatan ini dilakukan dengan mebuat kelompok kecil beranggotakan siswa dengan kemampuan membaca yang sama (homogen). Meski, mereka berkumpul dalam kelompok yang mempunyai kemampuan kelompok sama, kelompok-kelompok tersebut dibuat berjenjang dari yang berkemampuan rendah, sedang dan tinggi. Dalam kegiatan membaca ini terdapat dua kelompok siswa yaitu yang terbimbing dan tidak terbimbing. Siswa yang terbimbing mendapatkan bimbingan dari guru sedangkan kelompok yang tidak terbimbing diberi tugas seperti memcahkan puzzle, mengisi kalimat rumpang dan lainnya.

Kegiatan membaca mandiri berbeda dengan dua kegiatan sebelumnya dimana peran guru semakin kecil. Sebaliknya, peran siswa menjadi lebih besar karena mereka dituntut banyak berlatih. Pada tahap ini, disediakan beragam buku baik fiksi dan non fiksi. Siswa membaca berbagai buku secara individu atau berpasangan. Buku yang dibaca bisa diambil dari koleksi buku yang dimiliki sekolah. Bahan bacaan juga bisa diambil dari paket buku berjenjang sesuai tingkat kemampuan membaca siswa. Meski peran guru semakin kecil, ada beberapa peran yang masih dimainkan oleh guru seperti membimbing dan mengarahkan jenis bacaan yang bervariasi.

Program selanjutnya adalah Pendampingan. Pendampingan merupakan tahap penting yang menjadi kelanjutan dari kegiatan pelatihan yang telah dilakukan. Tahap pendampingan merupakan serangkaian kegiatan sistematis yang dilakukan untuk memastikan keberhasilan implementasi dari suatu program yang telah direncanakan sebelumnya. Tahap pendampingan meliputi empat tahap kegiatan yang meliputi Plan I, Plan II, DO, dan SEE.

1. Plan I

Tahap Plan I adalah tahap dimana detail perencanaan dilaksanakan. Dalam tahap ini, peran narasumber atau fasilitator tetap diperlukan dalam mendampingi jalannya kegiatan. Pada awal kegiatan, narasumber atau fasilitator mereview semua strategi membaca berimbang yang telah disampaikan. Sebagai tindak lanjutnya, narasumber atau fasilitator menekankan kepada semua peserta akan pentingnya Lesson Study bagi guru kelas awal. Kegiatan ini dimaksudkan 
agar semua guru yang menjadi peserta dapat menyusun perencanaan kegiatan pembelajaran (RPP) dan menerapkan strategi baik yang bersama maupun terbimbing.

Kegiatan ini berisi pengelompokan guru-guru peserta pelatihan kedalam kelompok-kelompok sesuai dengan level/ kelas atau kemampuan membaca siswa dan diskusi untuk mempersiapkan keperluan-keperluan yang akan digunakan dalam Plan 2 atau simulasi dan DO. Selain itu, kegiaan ini juga diisi dengan menyiapkan RPP untuk pembelajaran dengan cara memasukkan program membaca bersama dan membaca terbimbing dalam kegiatan pembelajaran.

Setelah itu, kegiatan ini diisi dengan menyiapkan buku besar/ Bigbook yang akan digunakan dalam kegiatan membaca bersama. Kemudian dilanjutkan dengan menyiapkan buku bacaan berjenjang (B3) untuk kegiatan membaca terbimbing. Dalam kegiatan ini, diberikan juga buku-buku yang memiliki kandungan isi dan nilai-nilai keislaman. Buku-buku tersebut diberikan oleh pengabdi secara langsung kepada perwakilan-perwakilan madrasah. Buku-buku tersebut merupakan buku yang menjadi acuan dan fokus utama dari pelatihan membaca berimbang ini. Diskusi dilanjutkan dengan menyiapkan kebutuhan dalam pembelajaran seperti lembar kegiatan, lembar latihan dan lainnya untuk siswa yang sedang tidak mengikuti kegiatan membaca terbimbing.

2. Plan II

Tahap Plan II adalah tahap kelanjutan dari Plan I yang terdiri dari simulasi kegiatan pembelajaran yang akan dilakukan berdasarkan RPP yang telah disusun pada tahap Plan I sebelumnya. Artinya, dalam Tahap Plan I sebelumnya telah dilakukan perencanaan bersama-sama untuk kemdian dipakai simulasi secara bersama-sama. Sebelum simulasi dimulai, seluruh guru peserta pelatihan langsung dikelompokkan sesuai dengan level atau kemampuan membaca siswa di kelas yang diajar. Simulasi ini harus disesuaikan dengan fokus kompetensi seperti memprediksi, memahami kosakata dan tanda baca, memahami isi bacaan, dan merangkum/meringkas. Kegiatan Plan II ini diikuti oleh 41 orang peserta yang sama dari 6 madrasah mitra UIN Walisongo.

Simulasi disertai dengan media pembelajaran yang digunakan serta disesuaikan dengan kompetensi dasar yang akan dicapai. Simulasi kegiatan membaca terbimbing menggunakan buku bacaan berjenjang (B3) dimana satu topik buku berisi 8 buah buku untuk digunakan 7 orang siswa dan satu orang guru. Setelah itu, simulasi juga dimungkinkan menggunakan bahan bacaan yang disiapkan yang mempunyai kandungan dan muatan nilai-nilai keislaman. Pada saat simulasi dilakukan, salah satu peserta atau guru model mensimulasikan RPP 
atau Skenario Pembelajaran yang telah disusun bersama yang memasukkan program membaca bersama dan membaca terbimbing dalam kegiatan pembelajaran. Pada saat yang sama, guru yang tidak melakukan simulasi melakukan pengamatan untuk kemudian dijadikan masukan refleksi bagi guru yang mengajar.

Setelah simulasi selesai, guru model melakukan melakukan refleksi diri (self reflection) terkait simulasi yang sudah dilaksanakan. Refleksi diri ini di mencakup hal-hal positif atau kelebihan-kelebihan kemudian diikuti dengan halhal negatif atau kekurangan dari kegiatan mengajar yang dilakukan. Setelah kedua pihak selesai melakukan refleksi, peserta dan guru model secara bersamasama mendiskusikan perbaikan-perbaikan yang akan dilakukan dan melakukan revisi atas RPP hingga lembar kerja penugasan. Selain itu, peserta juga mendiskusikan beberapa komponen yang sudah dilakukan dan yang belum dilakukan seperti membuat kesepakatan tentang posisi duduk yang baik, cara membuka buku apakah dari bagian bawah, tengah atau atas, dan lain sebagainya. 3. $\mathrm{DO}$

Tahap Do merupakan rangkaian kegiatan setelah Plan I dan II dilaksanakan. Tahap ini merupakan tahap dimana seluruh peserta melakukan apa yang sudah direncanakan termasuk penggunaan media pembelajaran. Kegiatan Do ini dilakukan oleh setiap guru di kelasnya masing-masing untuk mempraktikkan seluruh strategi yang telah dipelajari, dibahas, dan diskusikan pada tahap sebelumnya. Ketika seorang guru mengajar, maka guru tersebut akan diamati oleh guru lain dari kelas parallel yang mempunyai level yang sama, atau oleh guru lain dari level yang levelnya lebih rendah atau lebih atas.

Ketika praktik mengajar selesai, guru tersebut kembali melakukan refleksi diri (self reflection) tentang segala hal yang telah dilakukan dalam proses pembelajaran termasuk hal-hal positif dan negatif. Selanjutnya, guru yang menjadi pengamat memberikan masukan seperti halnya pada tahap Plan II. Pengamat memberikan masukan kepada guru terkait performa guru dalam mengajar, metode yang digunakan, dan materi yang disampaikan. Semua masukan dari kedua belah pihak akan menjadi input yang sangat berharga bagi guru yang melakukan praktik khususnya untuk perbaikan dalam mengajarkan membaca dengan strategi berimbang.

Setelah input dan masukan terinventarisir, guru yang praktik perlu mengumpulkan semua perangkat dan media pembelajaran yang digunakan. Selain itu, guru perlu membuat catatan tentang pelaksanaan untuk kemudian dibawa kedalam kegiatan SEE. Beberapa media serta hasil karya siswa dari 
proses pembelajaran perlu di kumpulkan dan diinventarisasi untuk dijadikan contoh bagi guru yang lain.

Setiap guru melakukan praktek pada tahap DO dua kali dengan pendampingan pengabdi. Pendamping yang merupakan pengabdi yang berjumlah dua orang mendampingi guru yang praktek secara acak namun merata.

Kegiatan DO dilaksanakan di masing-masing sekolah mitra yaitu MIN Sumur Rejo kec Gunung pati, MI Walisongo kec Jrakah, MI Miftahussibyan kec Tugu, MI Miftahul Akhlaqiyah kec Ngaliyan, MI Nurul Islam kec Ngaliyan, dan MI Darul Ulum Ngaliyan. Garis besar pelaksanaan pembelajaran hampir sama antar satu madrasah dengan yang lainnya karena skenario pembelajaran adalah sesuai dengan yang sudah disepakati pada tahap sebelumnya. Hasil dari monitor dan evaluasi atas pelaksanaan program membaca berimbang adalah:

Guru kelas awal mengajar di kelasnya masing-masing untuk mempraktikkan seluruh strategi yang telah dipelajari, bahas, dan diskusikan pada tahap sebelumnya. Ketika seorang guru mengajar, maka guru tersebut akan diamati oleh guru lain dari kelas parallel yang mempunyai level yang sama seperti kelas 1, 2, dan 3 dari sekolah yang sama, atau oleh guru lain dari level yang levelnya lebih rendah atau lebih atas.

Pada tahap ini, guru kelas awal fokus mempraktikkan strategi membaca bersama dan terbimbing. Hal ini karena pada tahap ini, diperlukan peran lebih guru pada saat praktik dilakukan yaitu membimbing dan mengarahkan siswa termasuk mengarahkan jenis bacaan yang bervariasi. Sangat berbeda dengan membaca mandiri dimana peran guru semakin kecil namun siswa dituntut banyak berlatih dan membaca beragam buku yang sudah disediakan.Ketika selesai praktik, guru tersebut kembali melakukan refleksi diri (self reflection) tentang segala hal yang telah dilakukan dalam proses pembelajaran termasuk halhal positif dan negatif disertai dengan masukan dari pengamat yang memberikan masukan kepada guru terkait performa guru dalam mengajar, metode yang digunakan, dan materi yang disampaikan. Semua masukan dari kedua belah pihak akan menjadi input yang sangat berharga bagi guru yang melakukan praktik khususnya untuk perbaikan dalam mengajarkan membaca dengan strategi berimbang. Kemudian, semua input dan masukan dikumpulkan oleh guru yang praktik termasuk semua perangkat dan media pembelajaran yang digunakan. Media serta hasil karya siswa dari proses pembelajaran di kumpulkan untuk dijadikan contoh bagi guru yang lain.

Adapun hasil refleksi dari praktik mengajar secara garis besar adalah guru jangan sampai lupa menyebutkan kontrak belajar karena hal tersebut akan 
berpengaruh pada proses pembelajaran; guru harus menyampaikan apersepsi untuk mempermudah siswa dalam mengikuti proses pembelajaran dan memahami materi; tugas yang diberikan kepada siswa hendaknya jangan terlalu mudah karena akan mengganggu siswa lain yang sedang mengikuti kegiatan membaca terbimbing; tugas yang diberikan kepada siswa jangan sampai terlalu sulit karena siswa tidak akan menyelesaikan tepat waktu; pengamat jangan terlalu campur tangan di kelas sehingga mengganggu jalannya proses belajar mengajar. Selain itu, guru akan kurang leluasa mengajar jika pengamat terlalu ikut campur atau bahkan melakukan intervensi; waktu yang digunakan harus direncanakan dengan baik sehingga kegiatan pembelajaran tidak memakan waktu lebih dari yang direncanakan sebelumnya; dan pengamat harus tepat dan disiplin dalam mengisi instrumen. Instrumen yang tepat akan menjadikan penilaian tepat dan terukur, jadi pengamat tidak cukup hanya mengandalkan hafalan.

4. SEE

Pada tahap ini, semua guru peserta dari 6 madrasah berkumpul di satu tempat yang sudah ditentukan untuk melakukan refleksi bersama. Mereka merefleksikan kegiatan yang telah dilaksanakan pada kegiatan DO. Setelah mereka semua berkumpul, mereka langsung dikumpulkan perkelas atau sesuai level. Selanjutnya bertukar dan berdiskusi tentang hasil pengamatan dan refleksi praktik mengajar menggunakan srategi membaca bersama dan terbimbing. Pada saat refleksi bersama berlangsung, semua guru yang telah mempersiapkan media penunjang menunjukkan dokumen dan lembar kerja untuk dilihat, diamati, dan dicermati guru-guru peserta dari sekolah lain. Media-media tersebut sangat membantu dalam memberikan gambaran pelaksanaan praktik mengajar serta ketercapaian tujuan pembelajaran.

Setelah sesi refleksi dan diskusi berakhir, semua peserta kembali berkumpul bersama untuk melakukan presentasi. Tiap kelas atau level membuat kesepakatan bersama terkait siapa yang akan memberikan presentasi. Salah satu dari perwakilan tiap kelas atau level memberikan presentasi secara klasikal tentang kelebihan dan kekurangan yang sudah dilakukan dalam kegiatan praktik mengajar. Pada sesi inilah semua guru peserta pelatihan belajar karena semua peserta meski dari kelas lain diberikan kesempatan yang sama untuk bertanya pada saat presentasi.

\section{PASCA PENDAMPINGAN}

Kegiatan pasca pendampingan terdiri dari pelaporan kegiatan dan penyerahan bukti pelatihan dan pendampingan kepada peserta. Kegiatan ini 
diikuti dengan harapan dan testimoni dari pihak madrasah mitra yang berharap agar program yang bagus seperti kegiatan pelatihan dan pendampingan ini dilanjutkan dimasa-masa yang akan datang. Pelaporan merupakan wujud tanggung jawab atas penyelenggaraan program sekaligus untuk mempermudah diseminasi hasil pelatihan.

\section{KESIMPULAN}

Pelatihan strategi membaca berimbang merupakan pelatihan yang menggunakan tiga strategi yaitu membaca bersama, terbimbing, dan mandiri. Pelatihan ini dimaksudkan untuk memudahkan dan mempercepat siswa dalam belajar membaca. Materi yang memiliki nilai-nilai keislaman dijadikan fokus yang dipelajari dan dikembangkan. Nilai-nilai keislaman didapatkan dari buku-buku yang dijadikan media utama yang dalam pelatihan ini diberikan madrasah binaan yang menjadi peserta.

Kegiatan membaca terbimbing hendaknya terus dilaksanakan secara kontinyu atau berkelanjutan untuk ragam tingkatan kemampuan membaca minimal seminggu sekali perkelompok. Selain itu, membaca mandiri menjadi program sekolah pada pagi hari atau setelah istirahat seminggu sekali untuk seluruh personel sekolah atau minimal tiap kelas. Tentunya, Kepala Madrasah dan guru harus mempunyai komitmen tinggi untuk melaksanakan programprogram membaca berimbang agar kegiatan dapat mensuport materi dan kompetensi membaca siswa atau peserta didik. Program kegiatan membaca berimbang yang dilaksanakan melalui tahapan lesson study dari beberapa madrasah hendaknya menjadi tali silaturrahim para guru untuk saling mendukung tercapainya pendidikan dan pengajaran yang berkualitas di seluruh MI.

\section{DAFTAR PUSTAKA}

Dalman. 2013. Keterampilan Membaca. Jakarta: PT RajaGrafindo Persada.

Darmadi, Hamid. 2010. Kemampuan Dasar Mengajar. Bandung: alfabeta

Rahim, Farida. 2008. Pengajaran Membaca di Sekolah Dasar. Jakarta: Bumi Aksara .

Soedarso. 1996. Sistem Membaca Cepat dan Efektif. Jakarta : Gramedia Utama. 
Wiryodijoyo, Suwaryono. 1989. Membaca: Srategi, Pengantar dan Tekniknya. Jakarta : P2LPTK.

www.prioritaspendidikan.org/id/post/70/hasil-asesmen-kemampuanmembaca-siswa-kelas-awal--egra--di-tujuh-provinsi--lancar-baca-huruftapi-sulit-menyimak

www.srie.org/2013/03/survei-pirls-literasi-membaca-siswa.html 
